IZA DP No. 5063

Immigrant Assimilation, Trust and Social Capital

James C. Cox

Wafa Hakim Orman

July 2010 


\title{
Immigrant Assimilation, Trust and Social Capital
}

\author{
James C. Cox \\ Georgia State University \\ Wafa Hakim Orman \\ University of Alabama in Huntsville \\ and IZA \\ Discussion Paper No. 5063 \\ July 2010 \\ IZA \\ P.O. Box 7240 \\ 53072 Bonn \\ Germany \\ Phone: +49-228-3894-0 \\ Fax: +49-228-3894-180 \\ E-mail: iza@iza.org
}

Any opinions expressed here are those of the author(s) and not those of IZA. Research published in this series may include views on policy, but the institute itself takes no institutional policy positions.

The Institute for the Study of Labor (IZA) in Bonn is a local and virtual international research center and a place of communication between science, politics and business. IZA is an independent nonprofit organization supported by Deutsche Post Foundation. The center is associated with the University of Bonn and offers a stimulating research environment through its international network, workshops and conferences, data service, project support, research visits and doctoral program. IZA engages in (i) original and internationally competitive research in all fields of labor economics, (ii) development of policy concepts, and (iii) dissemination of research results and concepts to the interested public.

IZA Discussion Papers often represent preliminary work and are circulated to encourage discussion. Citation of such a paper should account for its provisional character. A revised version may be available directly from the author. 
IZA Discussion Paper No. 5063

July 2010

\section{ABSTRACT}

\section{Immigrant Assimilation, Trust and Social Capital ${ }^{*}$}

Trust is a crucial component of social capital. We use an experimental moonlighting game with a representative sample of the U.S. population, oversampling immigrants, to study trust, positive, and negative reciprocity between first-generation immigrants and native-born Americans as a measure of immigrant assimilation. We also survey subjects in order to relate trusting and trustworthy behavior with demographic characteristics and traditional, surveybased measures of social capital. We find that immigrants are as trusting as native-born U.S. citizens when faced with another native-born citizen, but do not trust other immigrants. Immigrants appear to be less trustworthy overall but this finding disappears when we control for demographic variables and the amount sent by the first mover. The length of time an immigrant has been a naturalized U.S. citizen appears to increase trustworthiness but does not affect trusting behavior. Women and older people are less likely to trust, but no more or less trustworthy.

JEL Classification: $\quad$ C93, J61

Keywords: moonlighting game, trust, reciprocity, immigration, experiment

Corresponding author:

Wafa Hakim Orman

Department of Economics and Information Systems

University of Alabama in Huntsville

301 Sparkman Drive

Huntsville, AL 35899

USA

E-mail:wafa.orman@uah.edu

* This research was supported by the NSF-supported Time-Sharing Experiments in the Social Sciences (TESS). We are grateful to Knowledge Networks, Inc. for conducting the experiment. 


\section{Introduction}

The problem of un-assimilated immigrants is broadly acknowledged as a root cause of terrorism and a serious national security concern. Unemployment, discontent, and alienation from broader society in immigrant ghettos across Western Europe and the UK turn them into potential breeding grounds for fundamentalism and extremism. (Roy, 2004).

Beyond speaking the language and adopting the traditions of one's adopted country, social capital can be a vital measure of the assimilation process. Putnam (2000) describes two kinds of social capital - bonding capital, which refers to the closeness of links within a community, and bridging capital, which refers to the links between communities. Immigrant communities have some amount of both, but the amount of bridging capital between immigrants and native communities can be an indicator of how well assimilated the immigrant community is. Trust and trustworthiness are key components of social capital (Knack and Keefer, 1997; Glaeser, Laibson, Scheinkman, and Soutter, 2000), and therefore the levels of trust and trustworthiness within a community, and between people of different communities, can serve as useful indicators of the social capital accumulated. At the same time, lack of trust and the presence of actively negative feelings can serve as useful measures of the levels of discontent and alienation that communities may or may not feel.

The purpose of this study is to examine the relative levels of bridging and bonding capital between first-generation immigrants and native-born Americans at an individual level, and compare this with among immigrant communities. We use experimental methods to study trust, positive, and negative reciprocity. We combine the experiment with a survey to more precisely learn what develops the two forms of social capital. We can relate it to demographic characteristics, income, education, and life experiences, which may be shaped by exclusionary attitudes of the native population, as studied in Australia by Louis, Duck, Terry, Schuller, and Lalonde (2007), or by competitive versus cooperative experiences (Johnson, Johnson, Tiffany, and Zaidman, 1984). Since the study was conducted using a Knowledge Networks panel, the respondents are a representative sample of the U.S. population, with immigrants oversampled.

The moonlighting game, developed by Abbink, Irlenbusch, and Renner (2000), is an effective way to measure trust, reciprocity, and trustworthiness. For our purposes, it is superior to an ordinary trust or investment game (Berg, Dickhaut, and McCabe, 1995; Glaeser, Laibson, Scheinkman, and Soutter, 2000; Carter and Castillo, 2002). It constrains the action set 
less, since subjects can send both positive and negative amounts, potentially taking money from the person they are paired with or punishing. This allows for the testing of trust and positive reciprocity as well as negative feelings and the fear of negative reciprocity. It also more closely mirrors the experience for illegal immigrants, who are especially susceptible to "punishment."

\section{Experiment Setup}

The setup of the game is as follows: Each individual is randomly assigned to being either a first mover or a second mover. Both first and second movers are credited with a money endowment of 10 dollars. Each first mover is given the task of deciding whether she wants to give to a randomly paired second mover none, some, or all of her endowment or take up to $\$ 5$ from the paired person. Any amounts given by the first mover are tripled by the experimenter, while any amounts taken by the first mover are not transformed. The second mover then decides how much to return to the first mover, and can also punish the first mover. Each dollar that the second mover gives to the paired first mover costs the second mover 1 dollar . Each three dollars that the second mover takes from the paired first mover costs the second mover one dollar, so that punishment is costly. The second mover's choices are constrained so as not to give either a negative payoff. All choices are required to be in integer amounts.

Respondents completed their questionnaires online at their convenience, and were randomly matched ex-post. Due to the nature of the survey, the strategy method (Falk, Fehr, and Fischbacher, 2000) is the only feasible way to elicit responses from the second mover. This has the added advantage of providing a full range of information on the second mover's responses to each possible decision by the first mover. Each second mover decides, for

each possible action of the first mover, whether she wants to give money to the paired first mover or take money from her.

The amount sent by the first mover is tripled so that joint profits, and welfare, are clearly maximized when there is a great degree of trust, leading to the entire amount being sent in anticipation of a "fair split" by the second mover. Following Dufwenberg and Gneezy (2000), beliefs about the behavior of the average person were elicited from both the first and the second mover, with a monetary reward for guessing correctly. Gaechter and Renner (2006) show that incentivized beliefs are more accurate than beliefs that are elicited without a monetary incentive. First movers were asked to guess the behavior of the average second mover, and second movers were asked to guess the 
behavior of the average first mover. This enables us to understand their motivations, and to distinguish between trust in anticipation of reciprocity (or reciprocity in response to trust) versus altruism - do people only send high amounts if they expect to have a significant portion of it returned (or if a large amount was sent to them)?

There are four types of pairings. Using I to represent an immigrant of one's own community, $\mathrm{N}$ to represent a US native, FM to represent the first mover and SM to represent the second mover, the pairings are: I (FM) I (SM), I (FM) - N (SM), N (FM) - I (SM), and N (FM) - N (SM). The pairings were arranged using the respondents' place of birth, which had been collected by Knowledge Networks previously. Subjects were randomly assigned to first mover or second mover status and treatments.

Subjects were informed of the region of origin of the person they were going to be matched with. The actual matching of responses was accordingly conducted ex-post, once all the surveys were completed. For example, a respondent listing their (or their parents) place of birth as Jordan was preassigned to the I (FM) - I (SM) treatment and informed that they will be matched with another randomly selected individual from the Middle East, living in the US. If they were assigned to the I (FM) - N (SM) or the N (FM) - I (SM) treatment, they were informed that they would be matched with a randomly selected American. A respondent listing their and their parents' place of birth as the US was informed that they will be matched with a randomly selected immigrant to the US if they were assigned to the I (FM) - N (SM) or N (FM) - I (SM) treatment, or with a randomly selected American if they were assigned to the N (FM) - N (SM) treatment. Immigrants from any particular region will be matched only with others from their own region in the I (FM) - I (SM) treatment. While interactions between different immigrant groups are an important topic of study, they are beyond the scope of this paper. Information about respondents' religion was not used to match subjects.

The survey included questions on whether the subject or anyone they know has ever been a victim of a hate crime or prejudice, to see whether these experiences made a person more or less likely to trust, take money or punish. It therefore provided a chance to see not just whether or not people punish or take money, but who did so, with respect to income, background, and life experiences. Data on income and educational background are collected in the standard set of demographic questions that preceded the survey. We also included selected core questions from the World Bank's questionnaire on social capital (Grootaert, Narayan, Jones, and Woolcock, 2004) to test if these measures of social capital serve as predictors of trusting and reciprocal be- 
havior versus punishment or taking money. The experiment was conducted online by Knowledge Networks. The subjects were a random sample of the United States population, and immigrants were oversampled. Subjects were existing members of the Knowledge Networks panel, who had been given the hardware required to complete surveys online using their TV sets. They were all paid based on the outcomes of the moonlighting game. There was no separate participation fee since all panelists are already compensated by Knowledge Networks for being on the panel.

\section{Hypotheses}

We separately identify the differences in trusting behavior within immigrant and native communities, as measured by the I (FM) - I (SM) and N (FM) - N (SM) treatments, and between immigrant and native communities, as measured by the I (FM) - N (SM) and N (FM) - I (SM) treatments.

We identify the demographic and other characteristics that make immigrants more or less likely to trust, take money, or punish. We expect that people with more bridging social capital will be more trusting of an individual from the "other" group, whether native or immigrant, than people with less bridging social capital. We test the following hypotheses:

H1: People will have more bonding social capital within their "own" community, whether immigrant or native-born American, than bridging social capital with those in the "other" community. Meaning, they will be more likely to trust someone in their "own" community by giving them money rather than taking money from them. They will be relatively less likely to give money to someone from the "other" community, and more likely to take money from them.

H2: People with more social capital as indicated by the survey will have higher incomes and human capital and will also show more trusting and less negative behavior. They will be more likely to give money than take, regardless of whom they are paired with.

In sum, we wish to identify the relative importance of individual human capital vis-à-vis positive (or negative) experiences in the adopted country on the development of bridging and bonding capital and the assimilation

process. We aim to further the understanding of immigrant assimilation and behavior, potentially aiding the design of immigration policy. This issue is crucial to the study of migration and immigrant communities, and for the long-term success of the American "melting pot." 


\section{Results}

Subjects were randomly assigned to treatment - see Table 1 and Table 2 . Tables 4 and 5, along with figures 1 and 2 show the the amounts sent by first and second movers in the various treatments. Figure 5 shows the average amount sent by second movers in each treatment in response to the amount sent by the first mover. Interestingly, while there are some outliers, the averages show that the typical person merely attempts to reduce the first mover's payoff by approximately the amount that was taken away from them, not more. Figures 6 and 7 show us how much first movers send relative to expected responses by the second mover, as measured by the elicited beliefs. We see that people send in an expectation of positive reciprocity, but also out of a fear of negative reciprocity. The people who take money tend to not trust the second mover to return a positive amount.

A Mann-Whitney test shows that the amount sent by the first mover in the Immigrant-Immigrant treatment is significantly different from all the others at the $5 \%$ level ( $\mathrm{p}$-value $=0.0468$ ), and different from the ImmigrantNative treatment at the $10 \%$ level $(p$-value $=0.0771)$. So it appears that immigrants trust other immigrants less than they trust native-born Americans. If we compare immigrant and native-born Americans as first movers facing an immigrant second mover, the native-born Americans send more $(2.38 \mathrm{v} / \mathrm{s} 1.14)$ but this difference is not significant; the p-value is 0.1535 . When paired with a native-born American as a second mover, the amounts that immigrant first-movers send are not significantly different from nativeborn Americans ( $\mathrm{p}$-value $=0.91$ ).

For the second movers, the Mann-Whitney test shows that immigrants send 0.794 on average; less than native-born Americans (who send 4.57 on average $)$ regardless of treatment $(\mathrm{p}$-value $=0.0035)$. However, there is no significant difference between what immigrant second movers return to native-born Americans and what they return to other immigrants.

All told, we can reject hypothesis H1. In fact immigrants appear, at first glance, to have more bridging social capital than bonding social capital.

The survey measures belonging to various types of groups, including religious, ethnic, professional, neighborhood etc. We are therefore able to observe those who do not belong to any groups at all, and find that they are significantly more likely to take money as first movers - the p-value is 0.02 .

We test the effects of education on trusting behavior and find that immigrants who take money as first movers rather than send have, on average, 1.5 fewer years of schooling. The p-value from a Mann-Whitney test is 0.024 . For native-born Americans, the effect is even stronger - those who take 
money have 1.7 fewer years of schooling and the p-value from the MannWhitney test is 0.008 . So we fail to completely reject hypothesis H2.

We then look at behavior by region, religion, and immigrant status. As indicated by figure 16, a Mann-Whitney test also shows that the amounts sent by first movers who attend religious services regularly and are immigrants is significantly different $(\mathrm{p}$-value $=0.016)$ from those who are not immigrants. For second movers this difference is not significant.

From responses to the question: "On a scale of 1 to 5 , do you believe that most people can be trusted (1), or that you can't be too careful in dealing with people (5)," we normalize the responses and construct a Z-score to measure trust. We also create a "trusting" indicator which equals one if the individual responds with either 1 or 2 .

We find that unlike Glaeser, Laibson, Scheinkman, and Soutter (2000), in our study, trust measured by the survey question is in fact a weak predictor of trusting behavior - first movers who respond with a 1 or 2 send more. A Mann-Whitney test is significant at the $10 \%$ level, with a p-value of 0.078. On the other hand, it does not predict trustworthy behavior at all, as measured by the second mover returning a positive sum. However, the normalized trust score is higher for second movers who return at least as much as the first mover sent them, with a p-value of 0.04 in a Mann-Whitney test. This is in line with Chaudhuri and Gangadharan (2007), who found that those who were trustworthy tended to be trusting but the reverse was not necessarily true. Mann-Whitney tests and Table 7 show that the trust levels are not significantly different between first and second movers. Also, when we control for demographic variables, trust by itself no longer matters except when we look exclusively at immigrants.

Tables 9 and 10 show the factors influencing trust and trustworthiness. We see that women and older people are less likely to trust. Interestingly, the amount that the first mover believes the second mover will return is less important than the belief that the second mover will send some positive amount. We now reject hypothesis $\mathrm{H} 2$ - education does not seem to make people more trusting, though it does weakly affect trustworthiness. Second movers with more years of schooling are more likely to return as much as the first mover sent them. Again, those who are trusting are more likely to return at least as much as the first mover sent them (Table 10, column 3). Religious attendance makes people less likely to trust, and interestingly also reduces trustworthiness by making people less likely to send at least as much as they received. Figure 18 shows an interesting dichotomy between immigrants who attend more than once a week versus immigrants who attend weekly.

Table 11 looks exclusively at immigrants. We now see the effect of the 
length of time spent as a US citizen and find that the longer the time an immigrant has been a US citizen, the more trustworthy they are as a second mover. However, it does not affect their trusting behavior as a first mover at all. On the other hand, they definitely trust other immigrants less than they trust native-born Americans, even though immigrants are no less trustworthy.

Table 8 lists the percentage of people in each country agreed with the statement "most people can be trusted" in the 2004 wave of the World Values Survey (the 1999 wave data was used for the countries that were not surveyed in the 2004 wave). This is also used as a dependent variable (though all countries are not covered) and we find that, counterintuitively, those from less trusting countries are more trustworthy as second movers. Perhaps we can attribute this to an element of immigrant self-selection - those who leave a country are systematically different from those who remain. However, there are strong regional effects too, with immigrants from the Middle East and South Asia being the least trusting and trustworthy.

In each case we see that those who do not belong to any social group at all are less trusting and slightly less trustworthy. The trust experiment is therefore able to capture an important element of social capital.

On the other hand, the first movers who responded that they or someone they knew had been victims of a hate crime actually sent more (3.56 on average) than those who did not (they sent 1.82 on average; $\mathrm{p}$-value $=$ 0.007). There was no significant different for second movers. This is true even when we look exclusively at immigrants.

\section{Conclusion}

Two major points jump out from all the results. The first is that immigrants are trusted less than native-born Americans, even (especially?) by other immigrants, but when we control for demographic variables and the amount sent by the first mover, they do not appear to deserve this lack of trust. The second is that while home country variables do not have a clear impact, the number of years spent as a US citizen (controlling for age) appear to make immigrants more trustworthy. We have no way of knowing if this is a cohort effect (different cohorts of immigrants are systematically different) or captures assimilation. Either way, the moonlighting trust game is in fact a good measure of trust and social capital, since those with low social capital are also not trusting in the game.

People are reciprocal, which is no surprise, but this reciprocity manifests 
itself so as to make the immigrants in the sample appear less trustworthy than they are, since they are trusted less. This lack of trust can potentially have far-reaching implications, hindering immigrants' ability to assimilate rapidly.

\section{References}

Abbink, K., B. Irlenbusch, And E. Renner (2000): "The moonlighting game: An experimental study on reciprocity and retribution," Journal of Economic Behavior 85 Organization, 42(2), 265-277.

Berg, J., J. Dickhaut, and K. McCabe (1995): "Trust, Reciprocity, and Social History," Games and Economic Behavior, 10(1), 122-142.

Carter, M. R., and M. Castillo (2002): "The Economic Impacts of Altruism, Trust, and Reciprocity: An Experimental Approach to Social Capital," Wisconsin-Madison Agricultural and Applied Economics Staff Papers 448, Wisconsin-Madison Agricultural and Applied Economics Department.

Chaudhuri, A., and L. Gangadharan (2007): "An Experimental Analysis of Trust and Trustworthiness," Southern Economic Journal, 73(4), 959-985.

Dufwenberg, M., And U. Gneezy (2000): "Measuring Beliefs in an Experimental Lost Wallet Game," Games and Economic Behavior, 30(2), $163-182$.

Falk, A., E. Fehr, And U. Fischbacher (2000): "Testing Theories of Fairness - Intentions Matter," IEW - Working Papers iewwp063, Institute for Empirical Research in Economics - IEW, forthcoming in: Games and Economic Behavior.

Gaechter, S., and E. Renner (2006): "The Effects of (Incentivized) Belief Elicitation in Public Goods Experiments," Discussion Papers 2006-16, The Centre for Decision Research and Experimental Economics, School of Economics, University of Nottingham.

Glaeser, E. L., D. I. Laibson, J. A. Scheinkman, and C. L. Soutter (2000): "Measuring Trust," The Quarterly Journal of Economics, 115(3), $811-846$. 
Grootaert, C., D. Narayan, V. N. Jones, and M. Woolcock (2004): "Measuring social capital: An integrated questionnaire," World Bank Working Paper 18, World Bank, Washington, DC.

Johnson, D. W., R. T. Johnson, M. Tiffany, and B. Zaidman (1984): "Cross-Ethnic Relationships: The Impact of Intergroup Cooperation and Intergroup Competition.," Journal of Educational Research, 78(2), 75 79.

Knack, S., And P. Keefer (1997): "Does Social Capital Have an Economic Payoff? A Cross-Country Investigation," The Quarterly Journal of Economics, 112(4), 1251-1288.

Louis, W. R., J. M. Duck, D. J. Terry, R. A. Schuller, and R. N. LALONDE (2007): "Why do citizens want to keep refugees out? Threats, fairness and hostile norms in the treatment of asylum seekers," European Journal of Social Psychology, 37(1), 53-73.

Putnam, R. D. (2000): Bowling Alone: The Collapse and Revival of American Community. Simon \& Schuster New York.

Roy, O. (2004): Globalized Islam: The Search for a New Ummah. Columbia University Press New York, The CERI series in comparative politics and international studies. 


\section{Appendix A: Figures and Tables}

Table 1: Subjects per treatment

\begin{tabular}{lcc}
\hline Item & Number & Percent \\
\hline N-N & 110 & 24 \\
I-N & 122 & 27 \\
N-I & 134 & 30 \\
I-I & 84 & 19 \\
\hline \hline Total & 450 & 100
\end{tabular}

Table 2: Immigrants by region

\begin{tabular}{lrr}
\hline Item & Number & Percent \\
\hline northern/western europe & 57 & 27 \\
eastern europe & 10 & 5 \\
south asia & 12 & 6 \\
east asia & 28 & 13 \\
south-east asia & 20 & 9 \\
latin america & 35 & 17 \\
the caribbean & 9 & 4 \\
north america & 34 & 16 \\
middle east/central asia & 7 & 3 \\
Total & 212 & 100 \\
\hline \hline
\end{tabular}


Table 3: Group membership

\begin{tabular}{lccc}
\hline & \multicolumn{3}{c}{ immigrant } \\
& no & yes & total \\
\hline trade or business association & 10 & 7 & 17 \\
professional association (doctors, teachers, veterans) & 41 & 31 & 72 \\
trade union or labor union & 36 & 18 & 54 \\
neighborhood committee & 19 & 17 & 36 \\
religious or spiritual group (e.g. church, mosque, temple, etc) & 89 & 69 & 158 \\
political group or movement & 12 & 9 & 21 \\
cultural group or association (e.g. arts, music, theater, film) & 17 & 16 & 33 \\
education group (e.g. parent-teacher association, school committee) & 29 & 19 & 48 \\
sports group & 25 & 17 & 42 \\
youth or student group & 15 & 8 & 23 \\
ngo or civic group (e.g. rotary club, red cross) & 8 & 4 & 12 \\
ethnic-based community group & 1 & 10 & 11 \\
other groups & 8 & 6 & 14 \\
none & 91 & 94 & 185 \\
\hline Total & 235 & 210 & 445
\end{tabular}


Table 4: Amounts sent by first mover, by treatment

\begin{tabular}{lccccc}
\hline \hline & \multicolumn{5}{c}{ Treatment } \\
& N-N & I-N & N-I & I-I & Total \\
\hline-5 & 4 & 4 & 7 & 5 & 20 \\
-4 & 0 & 1 & 0 & 0 & 1 \\
-3 & 1 & 2 & 2 & 0 & 5 \\
-2 & 2 & 3 & 3 & 8 & 16 \\
-1 & 3 & 1 & 2 & 1 & 7 \\
0 & 8 & 10 & 14 & 6 & 38 \\
1 & 8 & 8 & 4 & 7 & 27 \\
2 & 6 & 5 & 9 & 4 & 24 \\
3 & 5 & 7 & 5 & 1 & 18 \\
4 & 1 & 1 & 0 & 0 & 2 \\
5 & 4 & 8 & 7 & 5 & 24 \\
6 & 1 & 0 & 0 & 0 & 1 \\
8 & 1 & 0 & 0 & 1 & 2 \\
9 & 1 & 0 & 3 & 1 & 5 \\
10 & 10 & 11 & 11 & 3 & 35 \\
Total & 55 & 61 & 67 & 42 & 225 \\
\hline \hline
\end{tabular}


Table 5: Amounts sent by second mover, by treatment

\begin{tabular}{lccccc}
\hline \hline & \multicolumn{5}{c}{ Treatment } \\
& N-N & I-N & N-I & I-I & Total \\
\hline-15 & 0 & 0 & 3 & 1 & 4 \\
-12 & 0 & 1 & 0 & 3 & 4 \\
-9 & 3 & 3 & 5 & 2 & 13 \\
-6 & 4 & 4 & 7 & 3 & 18 \\
-3 & 3 & 7 & 5 & 3 & 18 \\
0 & 9 & 7 & 12 & 2 & 30 \\
1 & 3 & 2 & 8 & 6 & 19 \\
2 & 4 & 3 & 5 & 1 & 13 \\
3 & 5 & 10 & 7 & 5 & 27 \\
4 & 1 & 3 & 0 & 6 & 10 \\
5 & 5 & 0 & 5 & 2 & 12 \\
6 & 4 & 3 & 2 & 1 & 10 \\
7 & 0 & 0 & 1 & 1 & 2 \\
8 & 0 & 0 & 0 & 2 & 2 \\
9 & 2 & 1 & 0 & 0 & 3 \\
10 & 1 & 5 & 2 & 2 & 10 \\
12 & 2 & 1 & 0 & 0 & 3 \\
14 & 0 & 2 & 0 & 1 & 3 \\
15 & 0 & 3 & 1 & 0 & 4 \\
19 & 1 & 0 & 0 & 0 & 1 \\
20 & 5 & 3 & 1 & 0 & 9 \\
25 & 2 & 3 & 0 & 0 & 5 \\
27 & 1 & 0 & 0 & 0 & 1 \\
30 & 0 & 0 & 1 & 0 & 1 \\
40 & 0 & 0 & 1 & 0 & 1 \\
Total & 55 & 61 & 66 & 41 & 223 \\
\hline \hline & & & & & \\
\hline
\end{tabular}




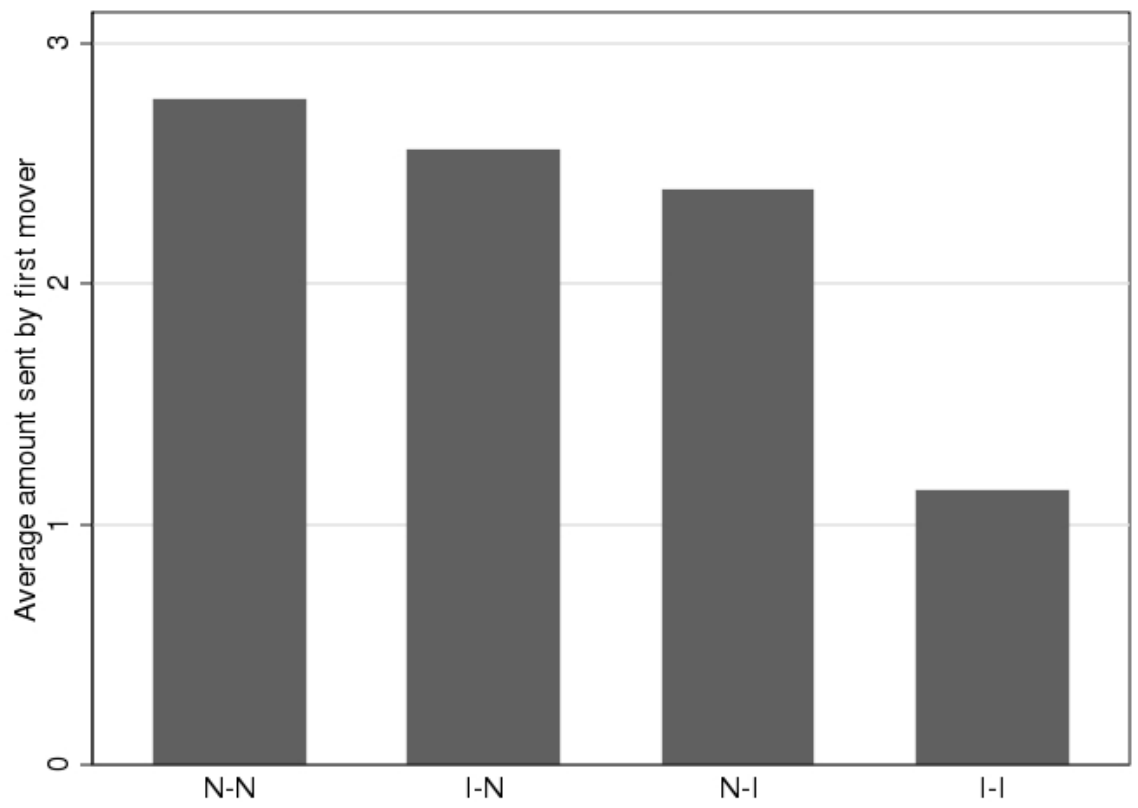

Figure 1: Average amount sent by first mover, by treatment

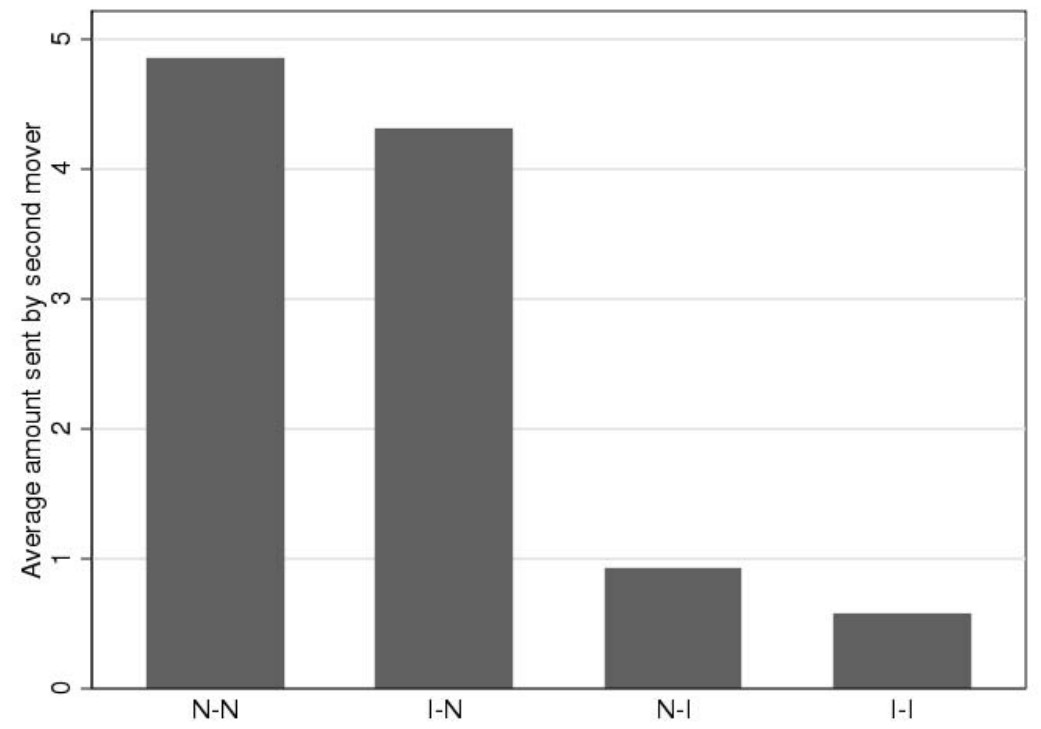

Figure 2: Average amount sent by second mover, by treatment 


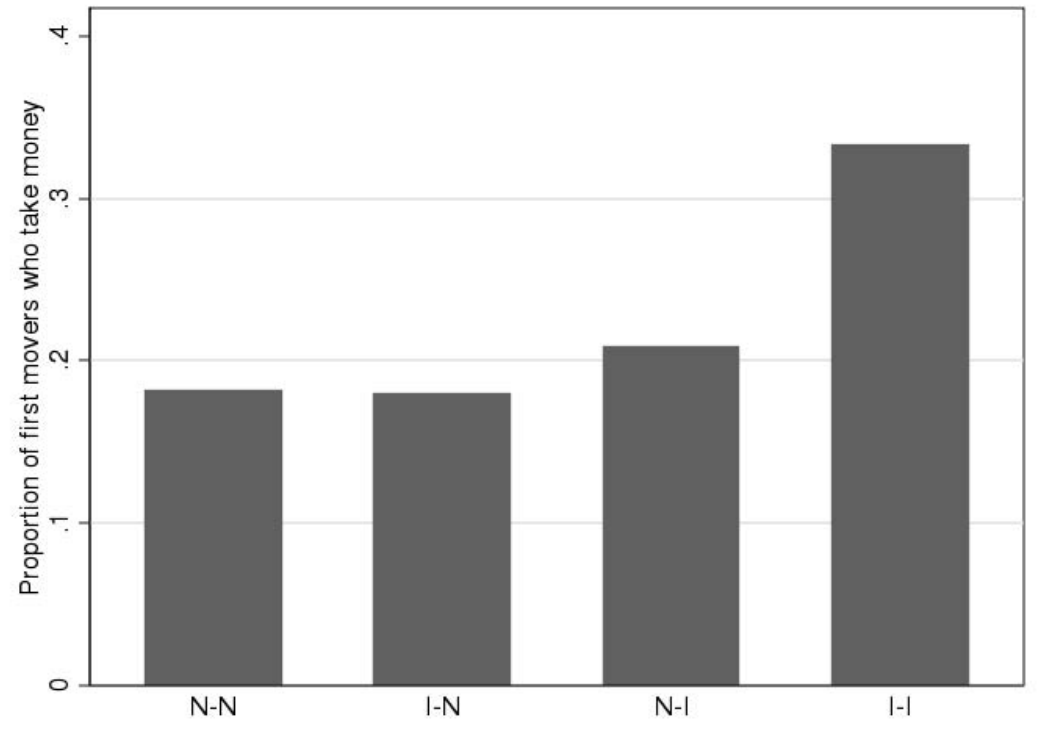

Figure 3: Proportion of first movers who take money from the second mover, by treatment

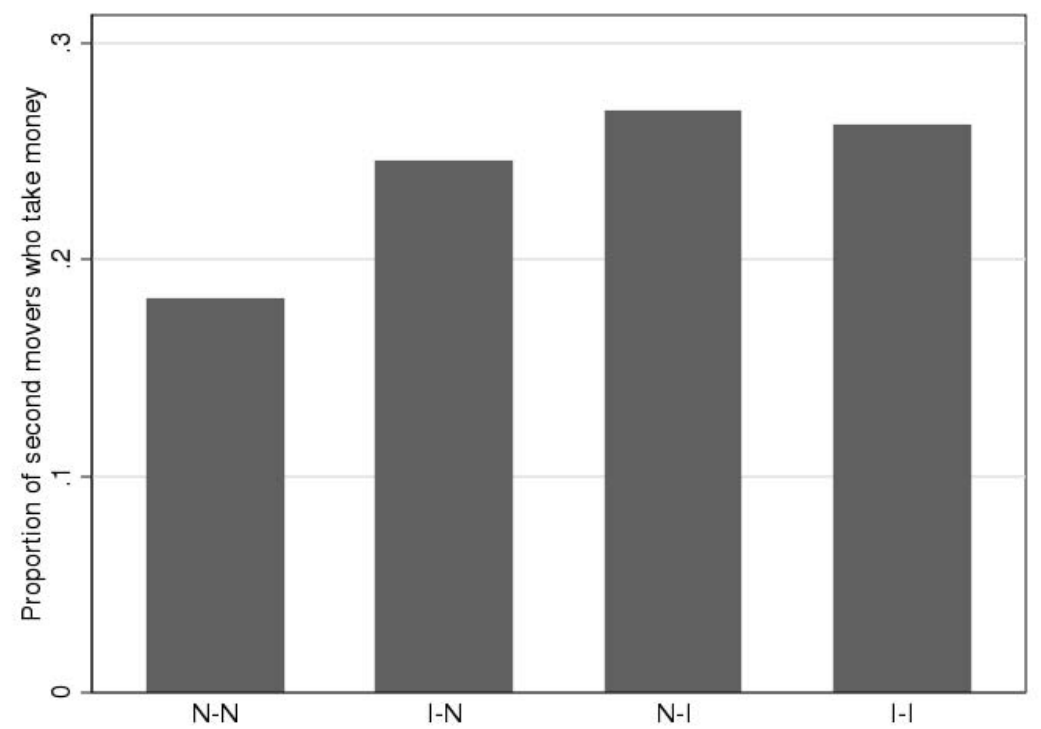

Figure 4: Proportion of second movers who take money from the first mover, by treatment 


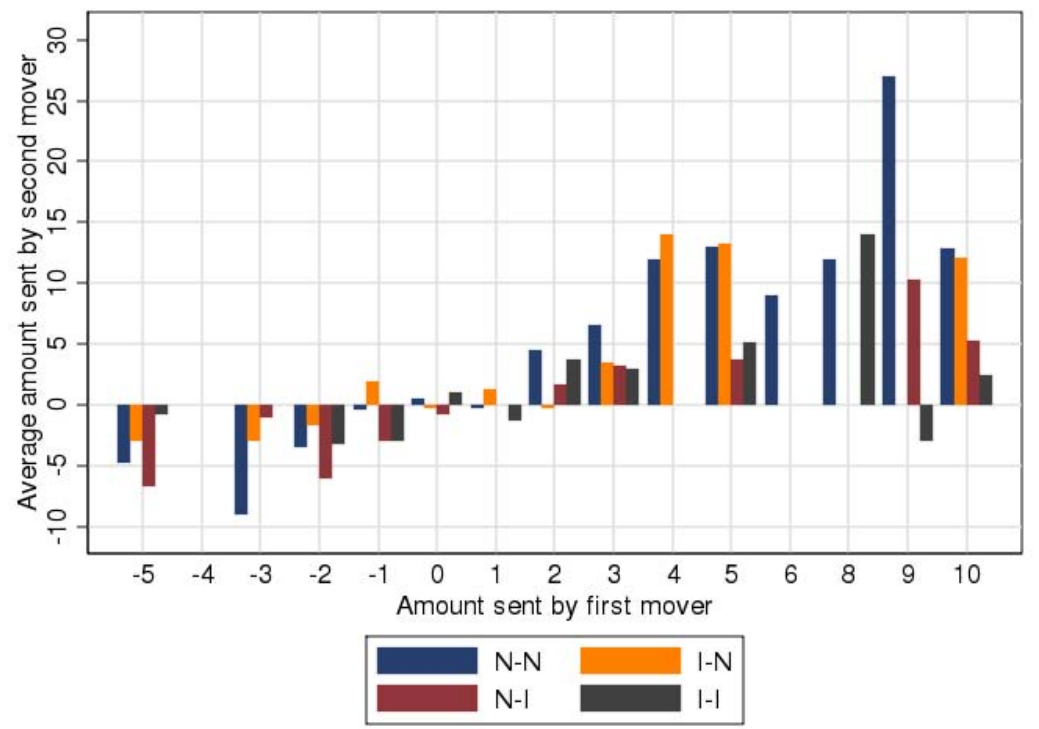

Figure 5: Second mover responses, by amount received from first mover and treatment

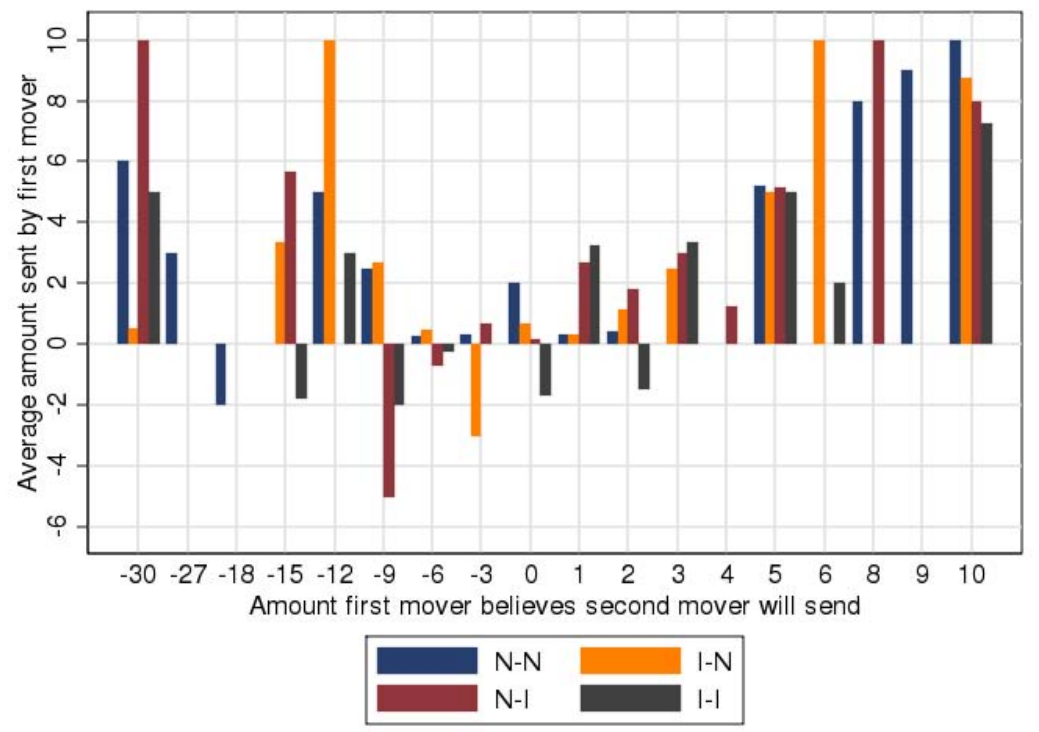

Figure 6: Amounts sent by first movers, by belief about second mover's action 


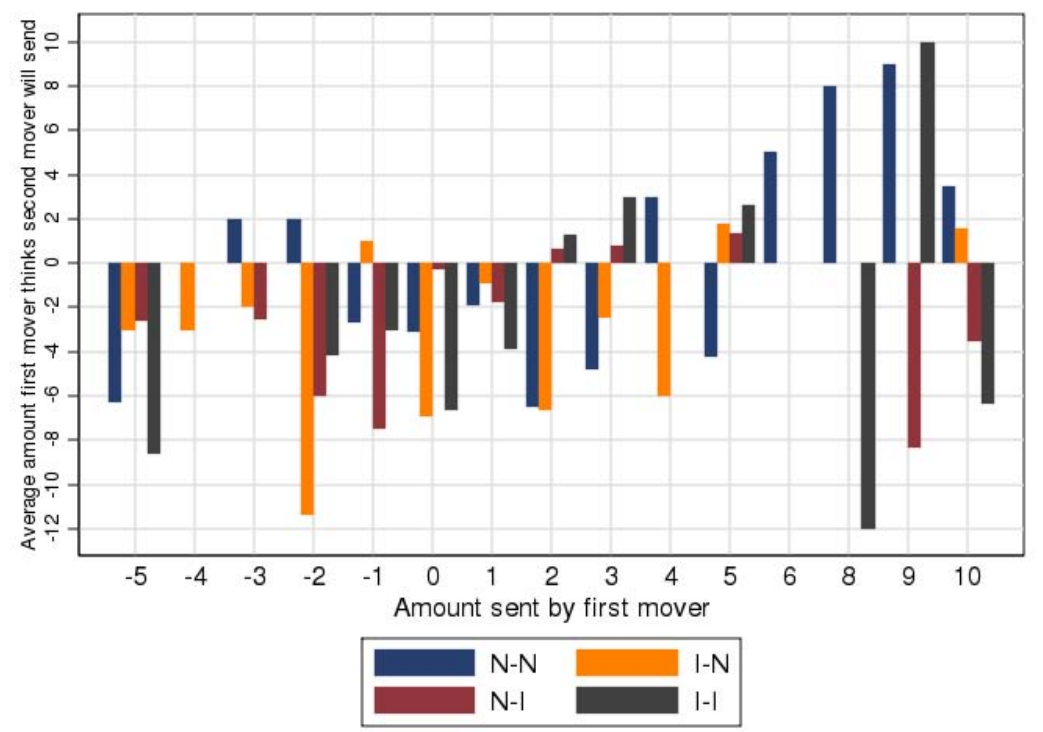

Figure 7: First mover's belief about second mover's action, by amount sent

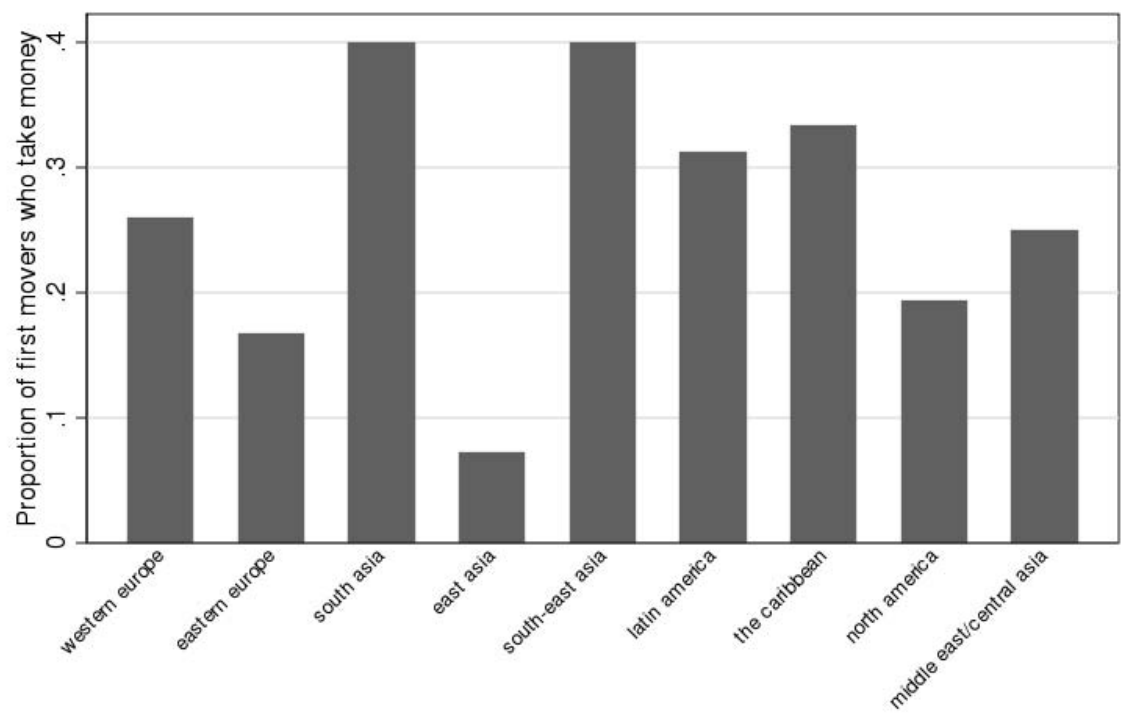

Figure 8: Proportion of first movers who take money from the second mover, by region 


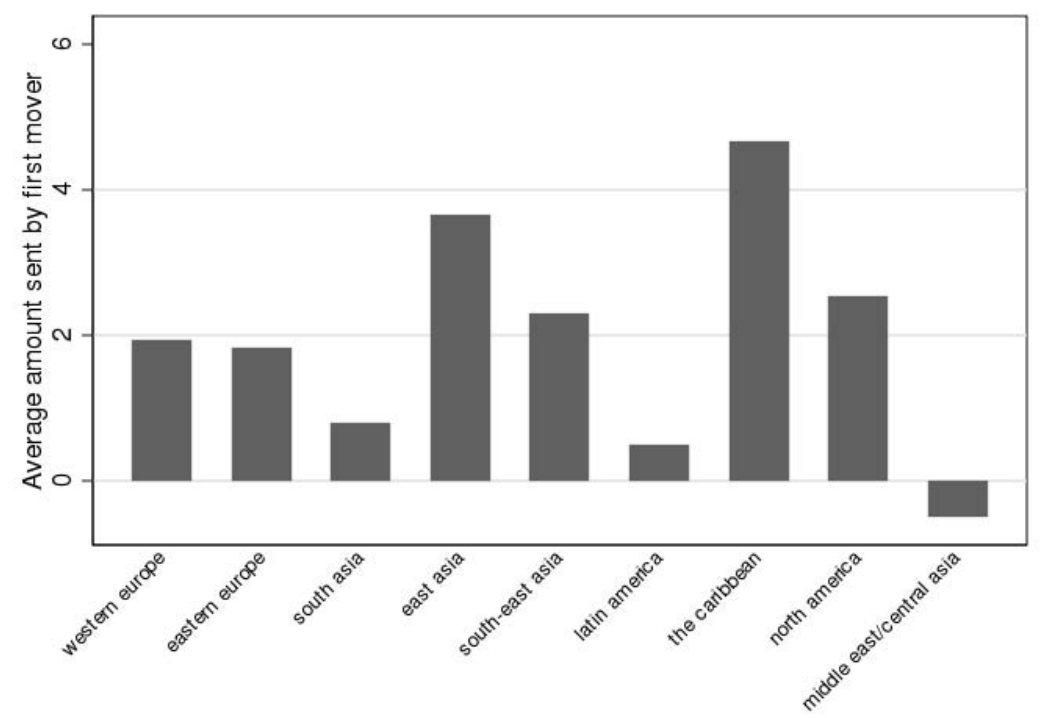

Figure 9: Average amount sent by first mover, by region

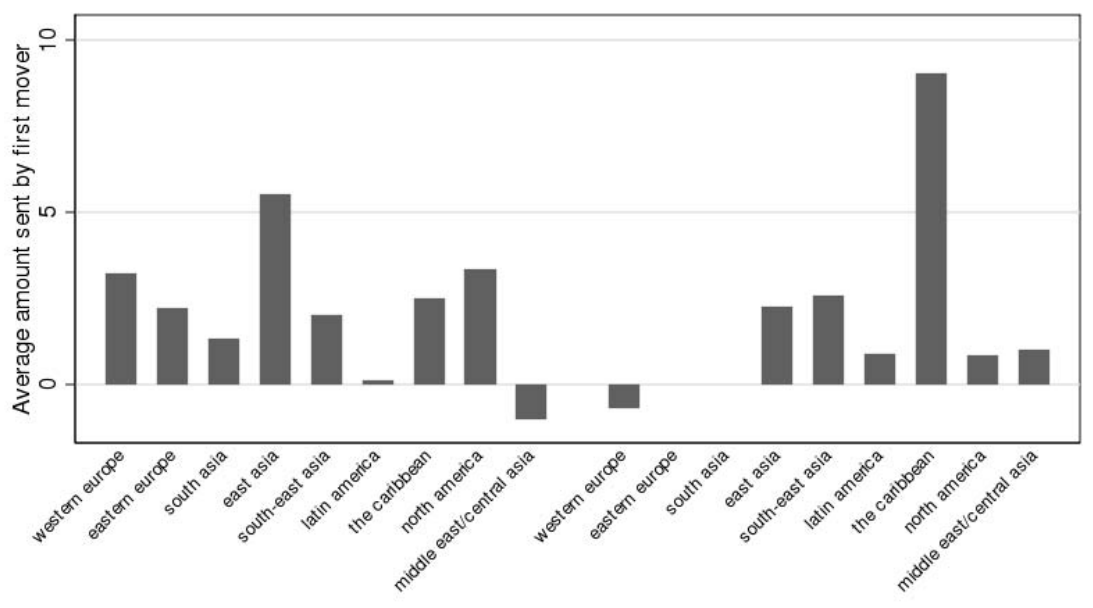

I-N

|-I

Figure 10: Average amount sent by immigrant first mover, by region and treatment 


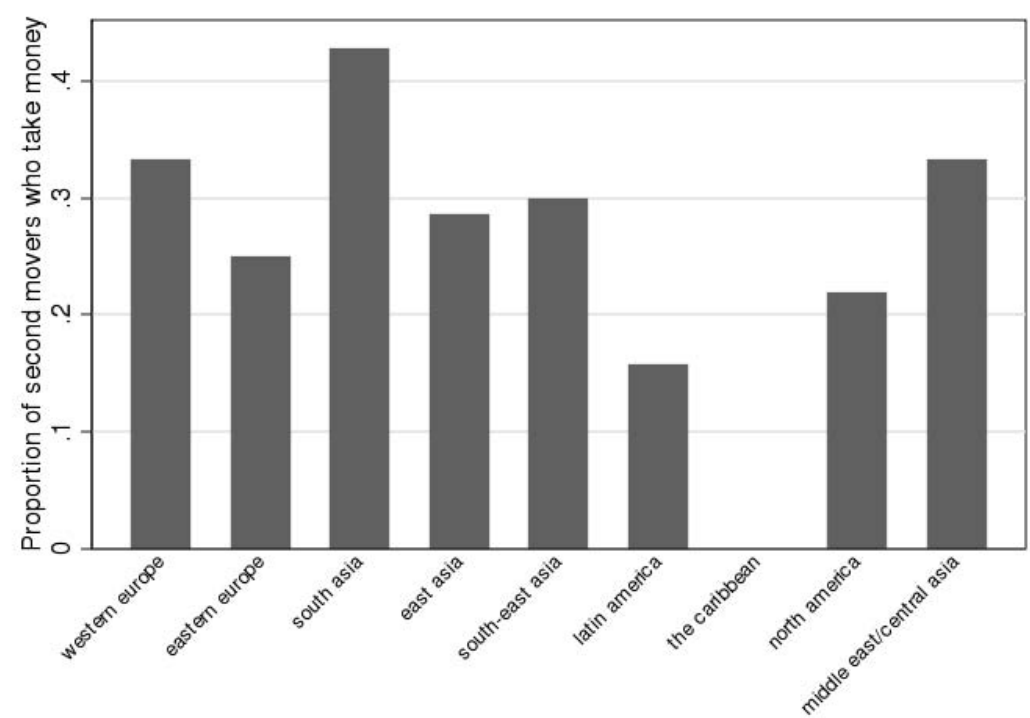

Figure 11: Proportion of second movers who take money from the second mover, by region

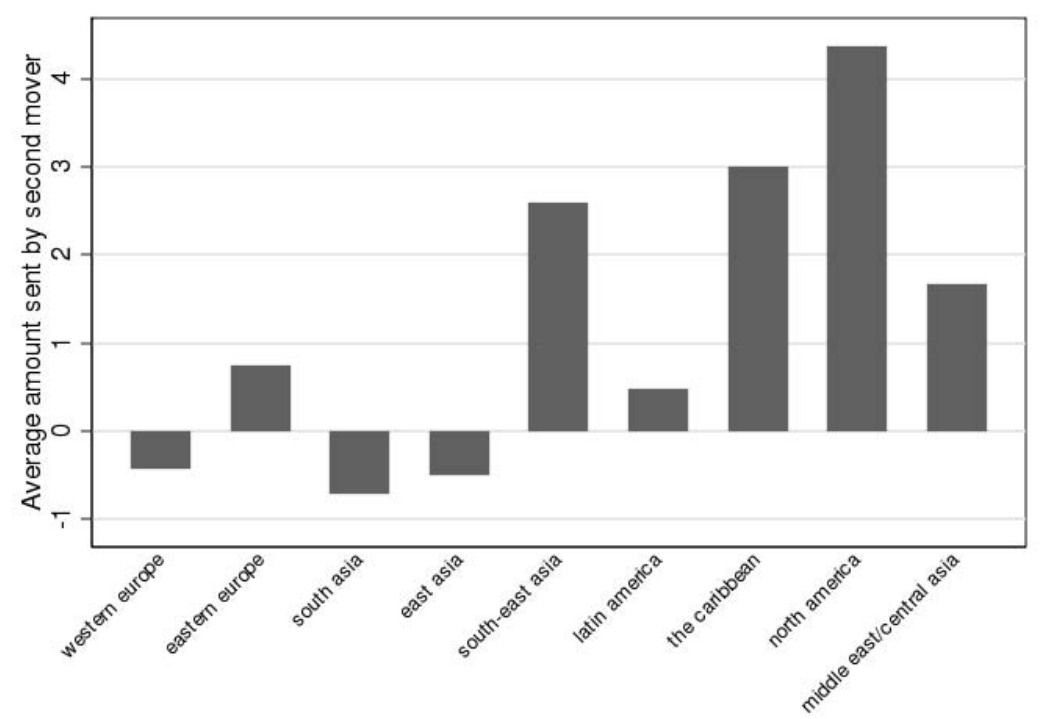

Figure 12: Average amount sent by second mover, by region 


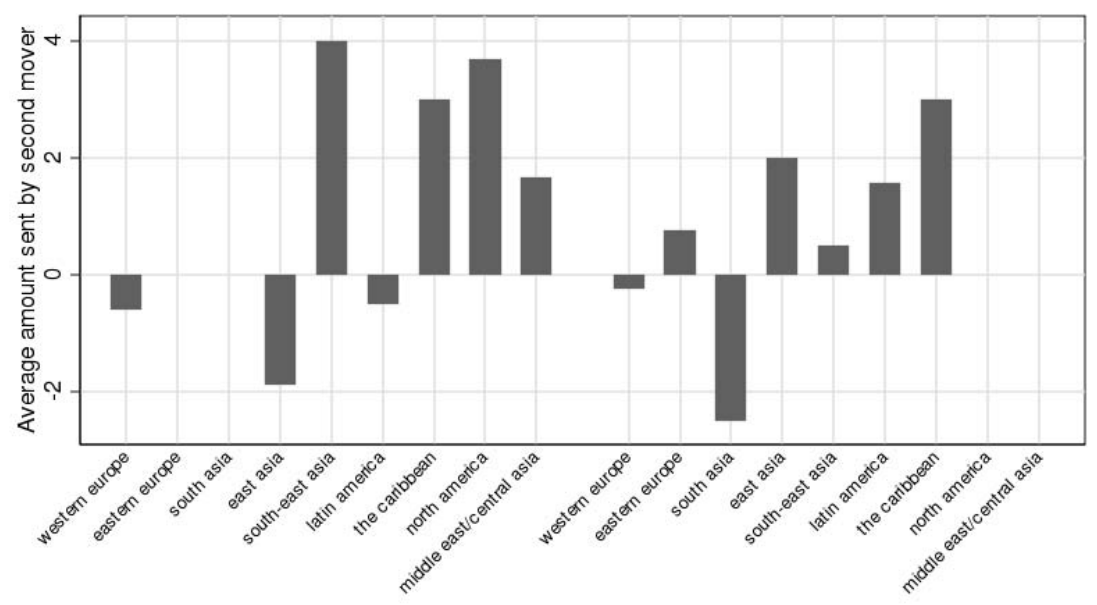

$\mathrm{N}-\mathrm{I}$

I-I

Figure 13: Average amount sent by second mover, by region and treatment

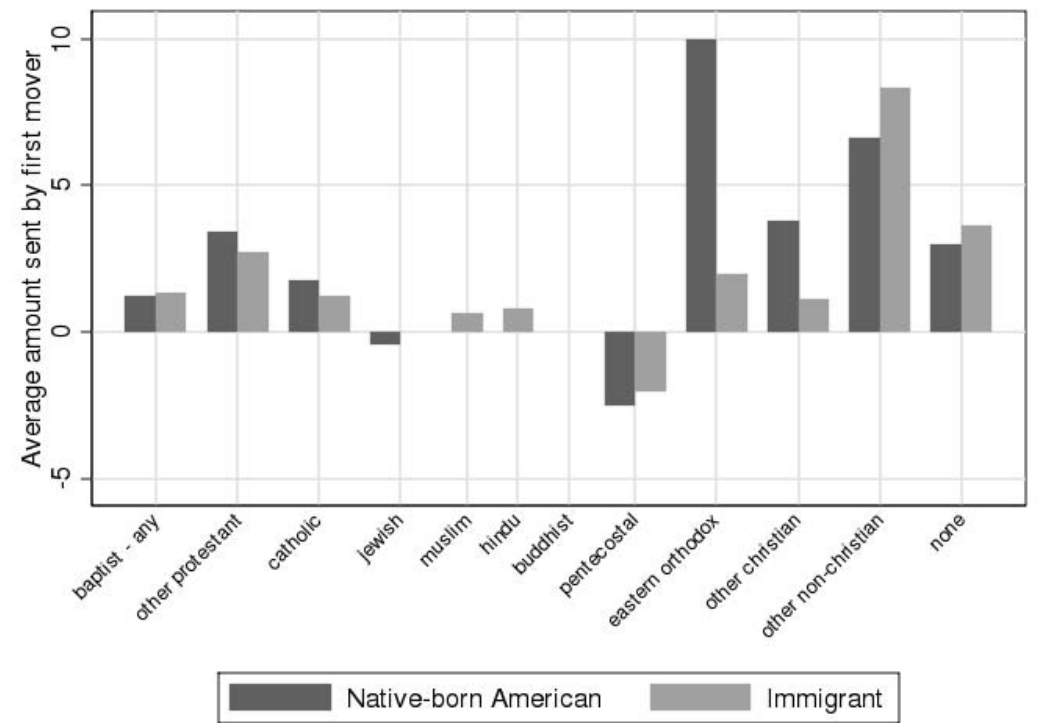

Figure 14: Average amount sent by first mover, by religion and immigrant status 


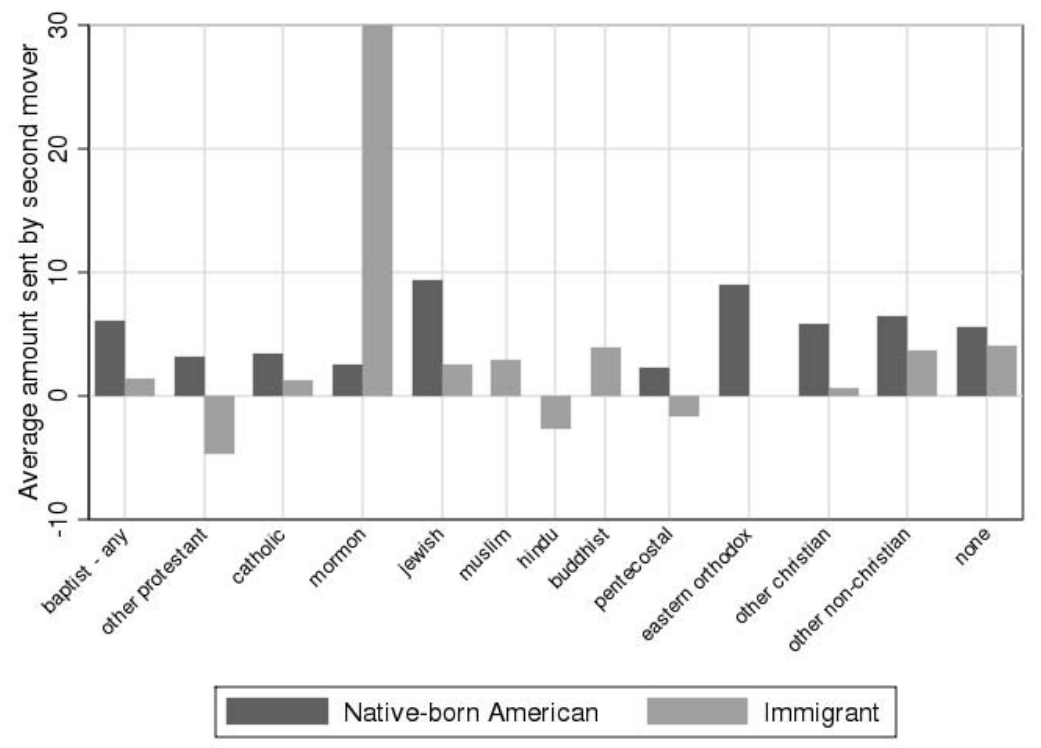

Figure 15: Average amount sent by second mover, by religion and immigrant status 


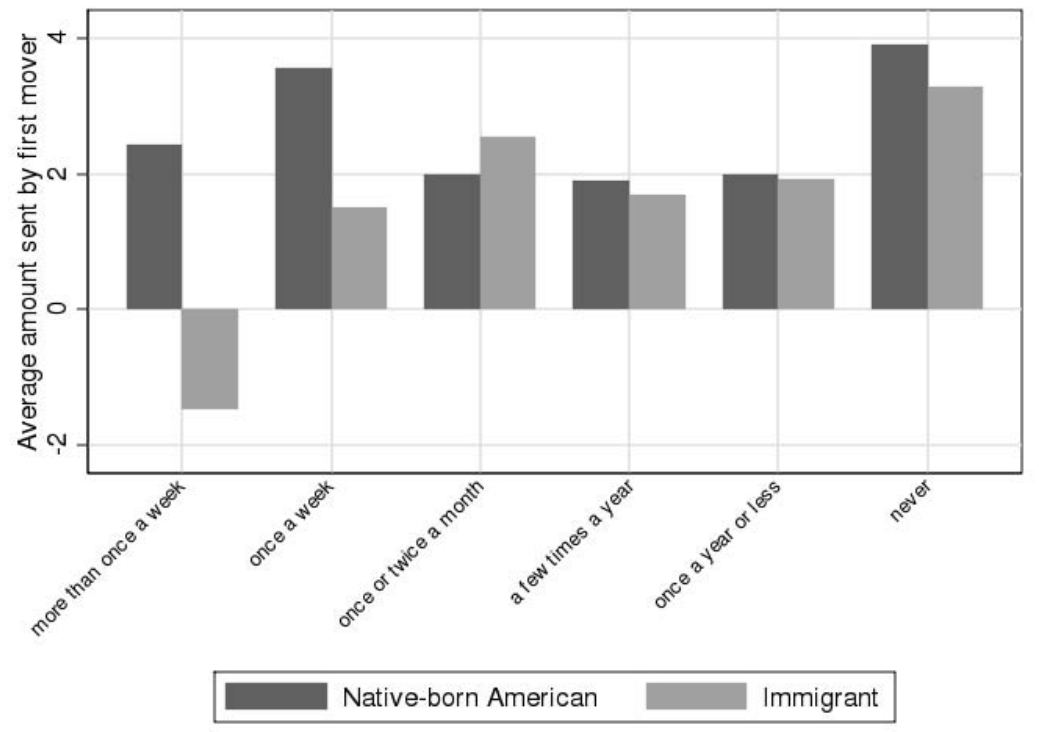

Figure 16: Average amount sent by first mover, by religious attendance and immigrant status

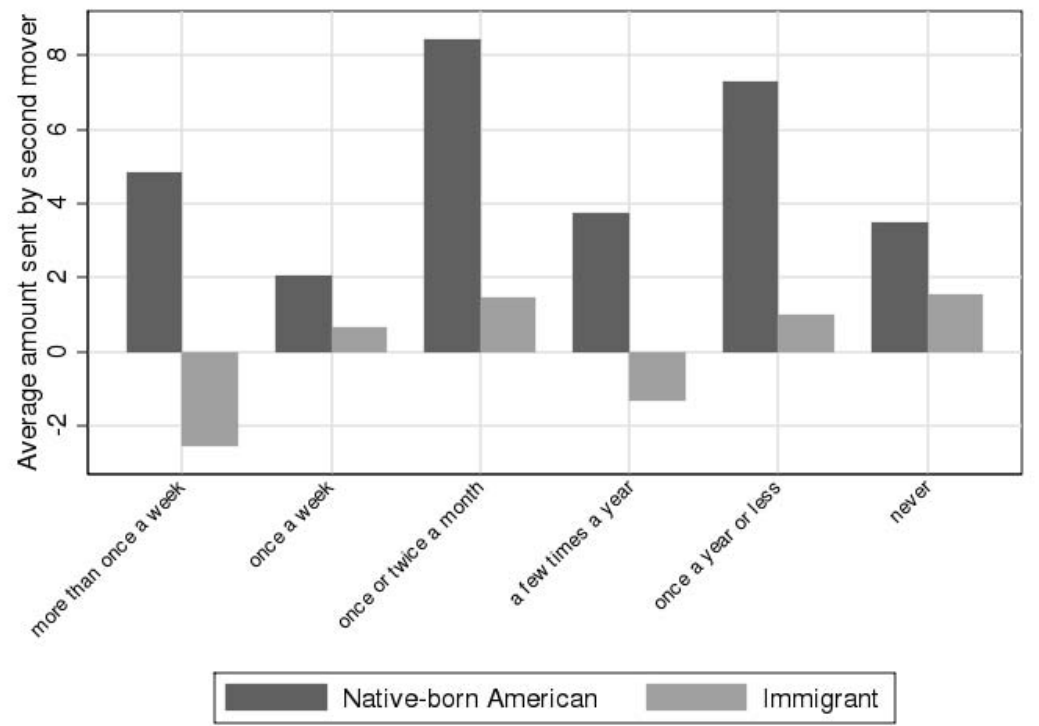

Figure 17: Average amount sent by second mover, by religious attendance and immigrant status 


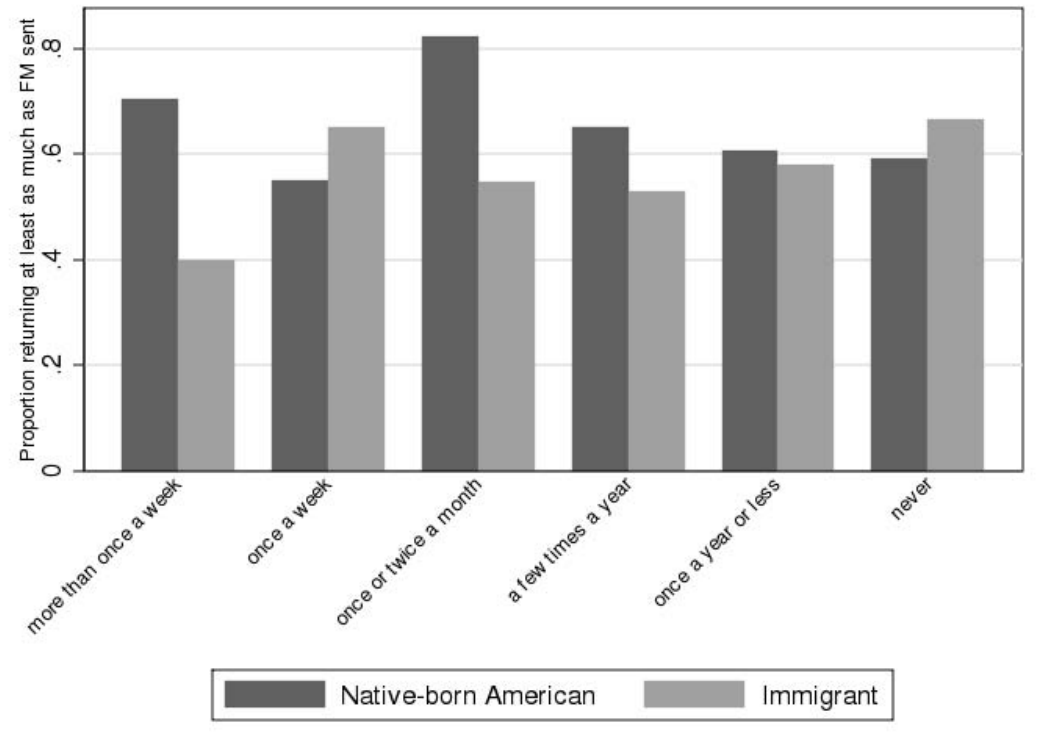

Figure 18: Proportion of second movers who return at least as much as first mover sent, by religious attendance and immigrant status 
Table 6: Responses to: Generally speaking, on a scale of 1 to 5, would you say that:

\begin{tabular}{lcc}
\hline Item & Number & Percent \\
\hline people can be trusted & 18 & 4 \\
2 & 127 & 28 \\
3 & 191 & 43 \\
4 & 87 & 19 \\
you can't be too careful in dealing with people & 24 & 5 \\
Total & 447 & 100 \\
\hline
\end{tabular}

Table 7: Trust by mover group

\begin{tabular}{lccc}
\hline & \multicolumn{3}{c}{ Mover group } \\
& First movers & Second movers & Total \\
\hline people can be trusted & 7 & 11 & 18 \\
2 & 72 & 55 & 127 \\
3 & 89 & 102 & 191 \\
4 & 46 & 41 & 87 \\
you can't be too careful in dealing with people & 9 & 15 & 24 \\
Total & 223 & 224 & 447 \\
\hline
\end{tabular}


Table 8:

Percent of people reported as "trusting" by country, World Values Survey

\begin{tabular}{lc}
\hline Home country & $\begin{array}{c}\text { Mean } \\
\text { \% people trusting }\end{array}$ \\
\hline canada & $36.96 \%$ \\
china & $53.42 \%$ \\
colombia & $10.80 \%$ \\
dominican republic & $26.45 \%$ \\
el salvador & $14.63 \%$ \\
former yugoslavia & $21.58 \%$ \\
germany & $35.41 \%$ \\
great britain & $29.25 \%$ \\
india & $39.43 \%$ \\
italy & $32.63 \%$ \\
japan & $42.69 \%$ \\
mexico & $26.50 \%$ \\
peru & $7.84 \%$ \\
philippines & $7.07 \%$ \\
poland & $18.16 \%$ \\
portugal & $12.31 \%$ \\
united states & $36.11 \%$ \\
vietnam & $41.13 \%$ \\
Total & $34.32 \%$
\end{tabular}


Table 9: First mover regression

\begin{tabular}{|c|c|c|}
\hline & $\begin{array}{c}(1) \\
\text { Ordered Logit }\end{array}$ & $\begin{array}{c}(2) \\
\text { OLS }\end{array}$ \\
\hline treatmentII & $\begin{array}{c}-0.910^{* *} \\
(0.425)\end{array}$ & $\begin{array}{l}-1.458^{*} \\
(0.792)\end{array}$ \\
\hline treatmentNI & $\begin{array}{l}-0.138 \\
(0.529)\end{array}$ & $\begin{array}{c}0.122 \\
(1.051)\end{array}$ \\
\hline treatmentNN & $\begin{array}{l}-0.314 \\
(0.520)\end{array}$ & $\begin{array}{l}-0.338 \\
(1.049)\end{array}$ \\
\hline female & $\begin{array}{c}-0.633^{* *} \\
(0.284)\end{array}$ & $\begin{array}{c}-1.382^{* *} \\
(0.611)\end{array}$ \\
\hline age & $\begin{array}{c}-0.0279 * * * \\
(0.009)\end{array}$ & $\begin{array}{c}-0.0622^{* * *} \\
(0.020)\end{array}$ \\
\hline belief about amount SM will return & $\begin{array}{c}-0.0239 \\
(0.031)\end{array}$ & $\begin{array}{c}-0.0775 \\
(0.060)\end{array}$ \\
\hline believe SM will return positive amount & $\begin{array}{c}1.550^{* * *} \\
(0.399)\end{array}$ & $\begin{array}{c}3.686^{* * *} \\
(0.848)\end{array}$ \\
\hline income in $1000 \mathrm{~s}$ & $\begin{array}{c}-0.0039 \\
(0.004)\end{array}$ & $\begin{array}{r}-0.0082 \\
(0.008)\end{array}$ \\
\hline years of schooling & $\begin{array}{l}0.0466 \\
(0.047)\end{array}$ & $\begin{array}{l}0.0592 \\
(0.103)\end{array}$ \\
\hline trusting & $\begin{array}{c}0.298 \\
(0.319)\end{array}$ & $\begin{array}{c}0.756 \\
(0.687)\end{array}$ \\
\hline religious attendance percentile & $\begin{array}{c}-1.080^{* *} \\
(0.532)\end{array}$ & $\begin{array}{c}-2.321^{* *} \\
(1.156)\end{array}$ \\
\hline belong to no social groups & $\begin{array}{c}-1.211^{* * *} \\
(0.368)\end{array}$ & $\begin{array}{c}-2.524^{* * *} \\
(0.758)\end{array}$ \\
\hline western europe & $\begin{array}{l}-0.161 \\
(0.598)\end{array}$ & $\begin{array}{l}-0.0955 \\
(1.181)\end{array}$ \\
\hline eastern europe & $\begin{array}{c}0.209 \\
(0.834)\end{array}$ & $\begin{array}{c}0.438 \\
(1.567)\end{array}$ \\
\hline south asia & $\begin{array}{l}-0.119 \\
(0.852)\end{array}$ & $\begin{array}{l}-0.131 \\
(1.662)\end{array}$ \\
\hline east asia & $\begin{array}{l}1.742^{* *} \\
(0.773)\end{array}$ & $\begin{array}{l}4.068 * * \\
(1.662)\end{array}$ \\
\hline south east asia & $\begin{array}{c}0.671 \\
(0.949)\end{array}$ & $\begin{array}{c}1.121 \\
(1.703)\end{array}$ \\
\hline latin america & $\begin{array}{l}-0.241 \\
(0.562)\end{array}$ & $\begin{array}{l}-0.573 \\
(1.165)\end{array}$ \\
\hline caribbean & $\begin{array}{c}2.186 \\
(1.837)\end{array}$ & $\begin{array}{c}5.052 \\
(3.530)\end{array}$ \\
\hline middle east/central asia & $\begin{array}{l}-1.002 \\
(1.708)\end{array}$ & $\begin{array}{l}-3.231 \\
(3.214)\end{array}$ \\
\hline
\end{tabular}




\begin{tabular}{lcc} 
Constant & & $\begin{array}{c}5.419^{* *} \\
(2.412)\end{array}$ \\
\hline Observations & 186 & 186 \\
R-squared & $\cdot$ & 0.285 \\
$* * * \mathrm{p}<0.01, * * \mathrm{p}<0.05,{ }^{*} \mathrm{p}<0.1$ & & \\
Robust standard errors in parentheses & &
\end{tabular}

Table 10: Second mover regression

\begin{tabular}{|c|c|c|c|}
\hline & $\begin{array}{c}\text { (1) } \\
\text { OLS }\end{array}$ & $\begin{array}{c}(2) \\
\text { Ordered Logit }\end{array}$ & $\begin{array}{c}\text { (3) } \\
\text { Logit: } \\
\text { SM return } \geq \text { FM sent }\end{array}$ \\
\hline treatmentII & $\begin{array}{c}.478 \\
(3.309)\end{array}$ & $\begin{array}{l}-.288 \\
(.700)\end{array}$ & $\begin{array}{l}-.505 \\
(.770)\end{array}$ \\
\hline treatmentNI & $\begin{array}{l}-.754 \\
(3.210)\end{array}$ & $\begin{array}{l}-.798 \\
(.642)\end{array}$ & $\begin{array}{l}-.994 \\
(.714)\end{array}$ \\
\hline treatmentNN & $\begin{array}{l}-.347 \\
(1.326)\end{array}$ & $\begin{array}{l}-.104 \\
(.340)\end{array}$ & $\begin{array}{l}-.227 \\
(.475)\end{array}$ \\
\hline female & $\begin{array}{c}.447 \\
(1.082)\end{array}$ & $\begin{array}{l}.117 \\
(.284)\end{array}$ & $\begin{array}{l}.135 \\
(.358)\end{array}$ \\
\hline age & $\begin{array}{l}-.071 \\
(.040)^{*}\end{array}$ & $\begin{array}{l}-.025 \\
(.011)^{* *}\end{array}$ & $\begin{array}{l}-.023 \\
(.013)^{*}\end{array}$ \\
\hline amount sent by FM & $\begin{array}{l}1.084 \\
(.148)^{* * *}\end{array}$ & $\begin{array}{c}.288 \\
(.042)^{* * *}\end{array}$ & $\begin{array}{l}.009 \\
(.039)\end{array}$ \\
\hline amount SM believes FM sent & $\begin{array}{c}.293 \\
(.233)\end{array}$ & $\begin{array}{l}.038 \\
(.061)\end{array}$ & $\begin{array}{l}.100 \\
(.061)\end{array}$ \\
\hline SM belief $>0$ & $\begin{array}{l}-.525 \\
(2.061)\end{array}$ & $\begin{array}{l}.231 \\
(.540)\end{array}$ & $\begin{array}{c}-.038 .000 \\
\quad(.595)\end{array}$ \\
\hline income in $1000 \mathrm{~s}$ & $\begin{array}{c}09 \\
(.015)\end{array}$ & $\begin{array}{l}-09 \\
(.004)\end{array}$ & $(.005)$ \\
\hline years of schooling & $\begin{array}{c}.377 \\
(.212)^{*}\end{array}$ & $\begin{array}{l}.091 \\
(.057)\end{array}$ & $\begin{array}{c}.131 \\
(.073)^{*}\end{array}$ \\
\hline trusting & $\begin{array}{l}1.276 \\
(1.178)\end{array}$ & $\begin{array}{l}.451 \\
(.314)\end{array}$ & $\begin{array}{l}.748 \\
(.447)^{*}\end{array}$ \\
\hline religious attendance percentile & $\begin{array}{l}-.826 \\
(1.937)\end{array}$ & $\begin{array}{l}-.444 \\
(.541)\end{array}$ & $\begin{array}{l}-1.237 \\
(.653)^{*}\end{array}$ \\
\hline belong to no social groups & $\begin{array}{l}-.009 \\
(1.176)\end{array}$ & $\begin{array}{l}-.133 \\
(.309)\end{array}$ & $\begin{array}{l}-.717 \\
(.386)^{*}\end{array}$ \\
\hline western europe & $\begin{array}{l}-3.119 \\
(3.345)\end{array}$ & $\begin{array}{l}.113 \\
(.746)\end{array}$ & $\begin{array}{l}-.069 \\
(.737)\end{array}$ \\
\hline eastern europe & $\begin{array}{c}.623 \\
(4.282)\end{array}$ & $\begin{array}{c}.849 \\
(1.177)\end{array}$ & $\begin{array}{l}1.336 \\
(1.619)\end{array}$ \\
\hline
\end{tabular}




\begin{tabular}{llll} 
south asia & -7.855 & -1.302 & -2.121 \\
& $(3.616)^{* *}$ & $(.889)$ & $(1.141)^{*}$ \\
east asia & -5.446 & -.711 & -1.327 \\
& $(3.334)$ & $(.739)$ & $(.980)$ \\
south-east asia & -3.644 & -.635 & -.642 \\
& $(3.515)$ & $(.766)$ & $(.924)$ \\
latin america & -5.404 & -.730 & -.488 \\
& $(3.405)$ & $(.719)$ & $(.789)$ \\
the caribbean & -2.788 & .053 & .201 \\
& $(3.752)$ & $(.983)$ & $(1.093)$ \\
middle east & -13.108 & -2.959 & \\
& $(3.673)^{* * *}$ & $(.823)^{* * *}$ & \\
\hline Obs. & 191 & 191 & \\
$R^{2}$ & .406 & & \\
$* * * \mathrm{p}<0.01, * * \mathrm{p}<0.05, * \mathrm{p}<0.1$ & & & \\
R & & &
\end{tabular}

Robust standard errors in parentheses 
Table 11: Ordered Logit: Immigrants Only

\begin{tabular}{|c|c|c|c|}
\hline & $\begin{array}{c}(1) \\
\text { FM amt }\end{array}$ & $\begin{array}{c}(2) \\
\text { SM amt }\end{array}$ & $\mathrm{SM}$ return $\geq \mathrm{FM}$ sent \\
\hline treatmentII & $\begin{array}{c}-2.344^{* * *} \\
(0.875)\end{array}$ & $\begin{array}{l}0.189 \\
(0.598)\end{array}$ & $\begin{array}{l}-.339 \\
(0.909)\end{array}$ \\
\hline female & $\begin{array}{l}-.678 \\
(0.885)\end{array}$ & $\begin{array}{l}-.588 \\
(0.591)\end{array}$ & $\begin{array}{c}0.106 \\
(0.821)\end{array}$ \\
\hline age & $\begin{array}{c}-.070^{* * *} \\
(0.022)\end{array}$ & $\begin{array}{c}-.135^{* * *} \\
(0.044)\end{array}$ & $\begin{array}{c}-.207^{* * *} \\
(0.061)\end{array}$ \\
\hline FM's belief about SM & $\begin{array}{c}-.096^{* * *} \\
(0.035)\end{array}$ & & \\
\hline FM's belief $>0$ & $\begin{array}{l}0.556 \\
(0.966)\end{array}$ & & \\
\hline FM's belief $>0$ x FM's belief & $\begin{array}{l}0.72^{* * *} \\
(0.232)\end{array}$ & & \\
\hline amount sent by FM & & $\begin{array}{l}0.251^{* *} \\
(0.103)\end{array}$ & 0.117 \\
\hline SM's belief $>0$ & & $\begin{array}{c}0.529 \\
(1.126)\end{array}$ & $\begin{array}{l}-2.025 \\
(2.125)\end{array}$ \\
\hline SM's belief about FM & & $\begin{array}{l}-.009 \\
(0.145)\end{array}$ & $\begin{array}{l}0.246 \\
(0.18)\end{array}$ \\
\hline income in $1000 \mathrm{~s}$ & $\begin{array}{l}-.002 \\
(0.01)\end{array}$ & $\begin{array}{c}0.00003 \\
(0.007)\end{array}$ & $\begin{array}{c}0.004 \\
(0.012)\end{array}$ \\
\hline years of schooling & $\begin{array}{l}-.124 \\
(0.13)\end{array}$ & $\begin{array}{c}0.191 \\
(0.127)\end{array}$ & $\begin{array}{l}0.565 \\
(0.32)\end{array}$ \\
\hline trusting & $\begin{array}{c}0.366 \\
(0.947) 3\end{array}$ & $1.850^{* *}$ & $\begin{array}{l}2.700^{* *} \\
(3) 3\end{array}$ \\
\hline religious attendance percentile & $\begin{array}{c}-6.092^{* * *} \\
(1.562)\end{array}$ & $\begin{array}{l}-.465 \\
(1.489)\end{array}$ & $\begin{array}{l}-1.200 \\
(1.349)\end{array}$ \\
\hline belong to no social groups & $\begin{array}{l}-4.147^{* * *} \\
(1.152)\end{array}$ & $\begin{array}{l}-.888 \\
(0.735)\end{array}$ & $\begin{array}{l}-1.563 \\
(1.070)\end{array}$ \\
\hline$\%$ trusting in home country & $\begin{array}{l}1.057 \\
(3.716)\end{array}$ & $\begin{array}{l}-4.805^{* * *} \\
(2.550)\end{array}$ & $\begin{array}{c}-10.483^{* * *} \\
(4.213)\end{array}$ \\
\hline \# years as US citizen & $\begin{array}{l}0.007 \\
(0.026)\end{array}$ & $\begin{array}{c}0.105^{* * *} \\
(0.035)\end{array}$ & $\begin{array}{c}0.178^{* * *} \\
(0.057)\end{array}$ \\
\hline Obs. & 49 & 45 & 45 \\
\hline
\end{tabular}




\section{Appendix B: Survey Questions}

The following questions were asked, in addition to demographic, religious and political responses already obtained by TESS:

1. Where were you born?

[select from standard list of countries using drop-down menu - standard list in HTML format is in Appendix C]

2. Where was your mother born?

[select from standard list of countries using drop-down menu]

3. Where was your father born?

[select from standard list of countries using drop-down menu]

[If respondent or either parent was not born in the USA, mark as Immigrant. Assign region as described in Appendix C. If respondent AND/OR both parents were born in the USA, mark as Native.]

4. Do you or any member of your household belong to any of the following groups (please check all that you belong to):

1 Trade or Business Association

2 Professional Association (doctors, teachers, veterans)

3 Trade Union or Labor Union

4 Neighborhood committee

5 Religious or spiritual group (e.g. church, mosque, temple, informal religious group, religious study group)

6 Political group or movement

7 Cultural group or association (e.g. arts, music, theater, film)

8 Education group (e.g. parent-teacher association, school committee)

9 Sports group

10 Youth or student group

11 NGO or civic group (e.g. Rotary Club, Red Cross)

12 Ethnic-based community group

13 Other groups 


\section{None}

[If respondent checks "None," skip the next three questions and go directly to question 10.]

5. Considering the group in which you participate most actively, how actively do you participate in this group? (select only one)

1 Leader

2 Very Active

3 Somewhat Active

4 Do not participate in decision-making

6. Thinking about the members of this group, are most of them of the same... (please select all that apply)

A. Neighborhood (yes/no)

B. Religion (yes/no)

C. Gender (yes/no)

D. Age (yes/no)

E. Ethnic or linguistic background, race, caste, or tribe (yes/no)

F. Income level (yes/no)

7. Does this group work or interact with other groups outside the neighborhood?

1 No

2 Yes, occasionally

3 Yes, frequently

8. About how many close friends do you have these days? These are people you feel at ease with, can talk to about private matters, or call on for help.

(enter a number)

9. There are often differences in characteristics between people living in the same neighborhood. For example, differences in wealth, income, social status, ethnic or linguistic background, race, caste, tribe, religion, or political beliefs. To what extent do any such differences characterize your neighborhood? 
1 To a very great extent

2 To a great extent

3 Neither great nor small extent

4 To a small extent

5 To a very small extent

10. In general, how safe from crime and violence do you feel when you are alone at home?

1 Very safe

2 Moderately safe

3 Neither safe nor unsafe

4 Moderately unsafe

5 Very unsafe

11. Have you or anyone you know personally ever been the victim of actual or threatened physical violence or harm as a result of your race, ethnicity, gender, religious or political beliefs etc (i.e. a hate crime) in the United States? (select all that apply)

1 Yes, I have

2 Yes, someone I know personally has

3 No, never

12. How often have you personally felt discriminated against in the United States because of your race, ethnicity, gender, religious, or political beliefs etc? (select only one)

1 Very often

2 Fairly often

3 Rarely

4 Never

13. Generally speaking, on a scale of 1 to 5 , would you say that most people can be trusted (1) or that you can't be too careful in dealing with people (5)? (select only one)

- People can be trusted

- You can’t be too careful in dealing with people 
14. In general, on a scale of 1 to 5 , would you say that: (select only one)

- Most people in my neighborhood are willing to help if you need it

- One has to be alert in my neighborhood, or someone is likely to take advantage of you

\section{Appendix C: Experiment Consent, Instructions, and Questions}

\section{Instructions and consent for First Mover}

[If respondent is in $\mathrm{I}(\mathrm{FM})$ - $\mathrm{I}(\mathrm{SM})$ or $\mathrm{N}(\mathrm{FM})$ - $\mathrm{N}(\mathrm{SM})$ treatment:] You and another randomly selected participant from [respondent's own region] have both been given $\$ 10$ by our research organization, which have been placed in your accounts.

[If respondent is in $\mathrm{I}(\mathrm{FM})$ - N(SM) treatment:] You and another randomly selected participant from the United States have both been given $\$ 10$ by our research organization, which have been placed in your accounts.

[If respondent is in $\mathrm{N}(\mathrm{FM})$ - I(SM) treatment:] You and another randomly selected participant, a first or second-generation immigrant to the United States, have both been given $\$ 10$ by our research organization, which have been placed in your accounts.

[Following is the same for all four treatments:] You are player 1, and the person you have been paired with is player 2. The game proceeds in two stages.

\section{Stage 1: Your decision}

In the first stage, you can decrease your account by any amount from $\$ 0$ to $\$ 10$, which will increase player 2's account by three times that amount. For example, if you decrease your account by $\$ 2$, player 2 's account increases by three times $\$ 2$, or by $\$ 6$. You will have $\$ 8$ in your account, and player 2 will have $\$ 16$ in their account.

Or, you can choose to increase your account by any amount from $\$ 0$ to $\$ 5$, which will decrease player 2's account by the same amount. For example, if you increase your account by $\$ 2$, player 2's account will decrease by $\$ 2$. You will have $\$ 12$ in your account, and player 2 will have $\$ 8$ in their account. 


\section{Stage 2: Player 2's decision}

In the second stage, after receiving the money, player 2 has two choices. He or she can decrease their account by any amount between $\$ 0$ and the amount present in their account after your decision, which will increase your account by that amount. For example, if player 2 decreases their account by $\$ 2$ and chooses to increase your account, your account will increase by $\$ 2$. You can keep whatever amount you receive from player 2 in addition to any money you chose not to send. Player 2 will keep whatever remains in their account.

Or, player 2 can decrease their account by any amount between $\$ 0$ and the amount present in their account after your decision, and decrease your account by three times that amount. For example, if player 2 decreases their account by $\$ 2$ and chooses to decrease your account, your account will decrease by $\$ 6$. You and player 2 will both keep whatever remains in your accounts.

What do you choose? (select only one option)

\begin{tabular}{l|c|c} 
& My account & Player 2's account \\
Current: & 10 & 10 \\
\hline 1 & +5 & -5 \\
2 & +4 & -4 \\
3 & +3 & -3 \\
4 & +2 & -2 \\
5 & +1 & -1 \\
6 & +0 & -0 \\
7 & -1 & +3 \\
8 & -2 & +6 \\
9 & -3 & +9 \\
10 & -4 & +12 \\
11 & -5 & +15 \\
12 & -6 & +18 \\
13 & -7 & +21 \\
14 & -8 & +24 \\
15 & -9 & +27 \\
16 & -10 & +30
\end{tabular}

[If respondent is in $\mathrm{I}(\mathrm{FM})$ - $\mathrm{I}(\mathrm{SM})$ or $\mathrm{N}(\mathrm{FM})$ - $\mathrm{N}(\mathrm{SM})$ treatment:] Now we would like you to guess what the average participant from [respondent's own region] would do as player 2, in response to your decision as player 1 .

[If respondent is in $\mathrm{I}(\mathrm{FM})$ - N(SM) treatment:] Now we would like you to guess what the average participant from the United States would do as 
player 2 , in response to your decision as player 1 .

[If respondent is in $\mathrm{N}(\mathrm{FM})$ - I(SM) treatment:] Now we would like you to guess what the average first or second-generation immigrant to the United States would do as player 2, in response to your decision as player 1 .

[Following is the same for all four treatments:]

If you guess correctly, or within $\$ 1$ of the correct answer, you will get a bonus of $\$ 5$. If the difference between your guess and the correct answer is more than $\$ 1$, you will get a bonus of $5 \div$ the absolute difference between your guess and the correct answer.

Select only one option:

1. Player 2 will decrease their own account by _-- and decrease player 1's account by three times that amount.

2. Player 2 will decrease their own account by --- and increase player 1's account by the same amount.

\section{Instructions and consent for Second Mover}

[If respondent is in $\mathrm{I}(\mathrm{FM})-\mathrm{I}(\mathrm{SM})$ or $\mathrm{N}(\mathrm{FM})-\mathrm{N}(\mathrm{SM})$ treatment:] You and another randomly selected participant from [respondent's own region] have both been given $\$ 10$ by our research organization, which have been placed in your accounts.

[If respondent is in $\mathrm{I}(\mathrm{FM})$ - N(SM) treatment:] You and another randomly selected participant from the United States have both been given $\$ 10$ by our research organization, which have been placed in your accounts.

[If respondent is in $\mathrm{N}(\mathrm{FM})$ - $\mathrm{I}(\mathrm{SM})$ treatment:] You and another randomly selected participant, a first or second-generation immigrant to the United States, have both been given $\$ 10$ by our research organization, which have been placed in your accounts.

[Following is the same for all four treatments:] You are player 2, and the person you have been paired with is player 1 . The game proceeds in two stages.

\section{Stage 1: Player 1's decision}

In the first stage, Player 1 can decrease their account by any amount from $\$ 0$ to $\$ 10$, which will increase your account by three times that amount. For example, if Player 1 decreases their account by $\$ 2$, your account increases by three times $\$ 2$, or by $\$ 6$. Player 1 will have $\$ 8$ in their account, and you will have $\$ 16$ in your account. 
Or, Player 1 can choose to increase their account by any amount from $\$ 0$ to $\$ 5$, which will decrease your account by the same amount. For example, if Player 1 increases their account by $\$ 2$, your account will decrease by $\$ 2$. Player 1 will have $\$ 12$ in their account, and you will have $\$ 8$ in your account.

\section{Stage 2: Your decision}

In the second stage, after receiving the money, you have two choices. You can decrease your account by any amount between $\$ 0$ and the amount present in your account after Player 1's decision, which will increase Player 1's account by that amount. For example, if you decrease your account by $\$ 2$ and choose to increase Player 1's account, Player 1's account will increase by $\$ 2$. Player 1 can keep whatever amount you receive from you in addition to any money you chose not to send. You will keep whatever remains in your account.

Or, you can decrease your account by any amount between $\$ 0$ and the amount present in your account after Player 1's decision, and decrease Player 1 's account by three times that amount. For example, if you decrease your account by $\$ 2$ and choose to decrease Player 1's account, Player 1's account will decrease by $\$ 6$. You and player 1 will both keep whatever remains in your accounts.

Since all the individuals in this study are being surveyed at different times, we will ask you what you would do after each possible decision by player 1. You will be paid according to the actual decision made by the individual you have been randomly matched with. You cannot make a choice that gives either you or Player 1 a negative payoff, and you cannot enter any decimal numbers or fractions.

1. If Player 1 increases their account by $\$ 5$, and reduces your account by $\$ 5$, what do you choose? (select only one option)

1 Decrease my account by _-- (enter a number between 0 and 5) and decrease player 1's account by three times that amount.

2 Decrease my account by _-- (enter a number between 0 and 5) and increase player 1's account by the same amount.

2. If Player 1 increases their account by $\$ 4$, and reduces your account by $\$ 4$, what do you choose? (select only one option)

1 Decrease my account by _-- (enter a number between 0 and 4) and decrease player 1's account by three times that amount. 
2 Decrease my account by --- (enter a number between 0 and 6) and increase player 1's account by the same amount.

3. If Player 1 increases their account by $\$ 3$, and reduces your account by $\$ 3$, what do you choose? (select only one option)

1 Decrease my account by _-- (enter a number between 0 and 4 ) and decrease player 1's account by three times that amount.

2 Decrease my account by --- (enter a number between 0 and 7 ) and increase player 1's account by the same amount.

4. If Player 1 increases their account by $\$ 2$, and reduces your account by $\$ 2$, what do you choose? (select only one option)

1 Decrease my account by _-- (enter a number between 0 and 4) and decrease player 1's account by three times that amount.

2 Decrease my account by _-- (enter a number between 0 and 8 ) and increase player 1's account by the same amount.

5. If Player 1 increases their account by $\$ 1$, and reduces your account by $\$ 1$, what do you choose? (select only one option)

1 Decrease my account by _-- (enter a number between 0 and 3) and decrease player 1's account by three times that amount.

2 Decrease my account by _-- (enter a number between 0 and 9 ) and increase player 1's account by the same amount.

6. If Player 1 increases their account by $\$ 0$, and reduces your account by $\$ 0$, what do you choose? (select only one option)

1 Decrease my account by _-- (enter a number between 0 and 3 ) and decrease player 1's account by three times that amount.

2 Decrease my account by _-- (enter a number between 0 and 10) and increase player 1's account by the same amount.

7. If Player 1 decreases their account by $\$ 1$, and increases your account by $\$ 3$, what do you choose? (select only one option)

1 Decrease my account by _-- (enter a number between 0 and 3) and decrease player 1's account by three times that amount. 
2 Decrease my account by --- (enter a number between 0 and 13) and increase player 1's account by the same amount.

8. If Player 1 decreases their account by $\$ 2$, and increases your account by $\$ 6$, what do you choose? (select only one option)

1 Decrease my account by _-- (enter a number between 0 and 2) and decrease player 1's account by three times that amount.

2 Decrease my account by --- (enter a number between 0 and 16) and increase player 1's account by the same amount.

9. If Player 1 decreases their account by $\$ 3$, and increases your account by $\$ 9$, what do you choose? (select only one option)

1 Decrease my account by _-- (enter a number between 0 and 2) and decrease player 1's account by three times that amount.

2 Decrease my account by _-- (enter a number between 0 and 19) and increase player 1's account by the same amount.

10. If Player 1 decreases their account by $\$ 4$, and increases your account by $\$ 12$, what do you choose? (select only one option)

1 Decrease my account by _-- (enter a number between 0 and 2) and decrease player 1's account by three times that amount.

2 Decrease my account by _-- (enter a number between 0 and 22) and increase player 1's account by the same amount.

11. If Player 1 decreases their account by $\$ 5$, and increases your account by $\$ 15$, what do you choose? (select only one option)

1 Decrease my account by _-- (enter either 0 or 1 ) and decrease player 1's account by three times that amount.

2 Decrease my account by --- (enter a number between 0 and 25) and increase player 1's account by the same amount.

12. If Player 1 decreases their account by $\$ 6$, and increases your account by $\$ 18$, what do you choose? (select only one option)

1 Decrease my account by --- (enter either 0 or 1 ) and decrease player 1's account by three times that amount. 
2 Decrease my account by --- (enter a number between 0 and 28) and increase player 1's account by the same amount.

13. If Player 1 decreases their account by $\$ 7$, and increases your account by $\$ 21$, what do you choose? (select only one option)

1 Decrease my account by --- (enter either 0 or 1 ) and decrease player 1's account by three times that amount.

2 Decrease my account by --- (enter a number between 0 and 31) and increase player 1's account by the same amount.

14. If Player 1 decreases their account by $\$ 8$, and increases your account by $\$ 24$, what do you choose? (select only one option)

1 Do nothing, leave the accounts as they are now.

2 Decrease my account by --- (enter a number between 0 and 34) and increase player 1's account by the same amount.

15. If Player 1 decreases their account by $\$ 9$, and increases your account by $\$ 27$, what do you choose? (select only one option)

1 Do nothing, leave the accounts as they are now.

2 Decrease my account by _-- (enter a number between 0 and 37) and increase player 1's account by the same amount.

16. If Player 1 decreases their account by $\$ 10$, and increases your account by $\$ 30$, what do you choose? (select only one option)

1 Do nothing, leave the accounts as they are now.

2 Decrease my account by --- (enter a number between 0 and 40) and increase player 1's account by the same amount.

[If respondent is in $\mathrm{I}(\mathrm{FM})$ - I(SM) or $\mathrm{N}(\mathrm{FM})$ - $\mathrm{N}(\mathrm{SM})$ treatment:] Now we would like you to guess what the average participant from [respondent's own region] would do as player 1.

[If respondent is in $\mathrm{I}(\mathrm{FM})$ - N(SM) treatment:] Now we would like you to guess what the average first or second-generation immigrant to the United States would do as player 2, in response to your decision as player 1 .

[If respondent is in $\mathrm{N}(\mathrm{FM})$ - I(SM) treatment:] Now we would like you to guess what the average participant from the United States would do as player 1. 
[Following is the same for all four treatments:]

If you guess correctly, or within $\$ 1$ of the correct answer, you will get a bonus of $\$ 5$. If the difference between your guess and the correct answer is more than $\$ 1$, you will get a bonus of $5 \div$ the absolute difference between your guess and the correct answer.

Select only one option:

\begin{tabular}{l|c|c} 
& Player 1's account & Player 2's account \\
At the start: & 10 & 10 \\
\hline 1 & +5 & -5 \\
2 & +4 & -4 \\
3 & +3 & -3 \\
4 & +2 & -2 \\
5 & +1 & -1 \\
6 & +0 & -0 \\
7 & -1 & +3 \\
8 & -2 & +6 \\
9 & -3 & +9 \\
10 & -4 & +12 \\
11 & -5 & +15 \\
12 & -6 & +18 \\
13 & -7 & +21 \\
14 & -8 & +24 \\
15 & -9 & +27 \\
16 & -10 & +30
\end{tabular}

